JIIA, VOLUME 6 No. 3, AGUSTUS 2018

\title{
PERAN PENGGUNAAN PUPUK PADA KINERJA PRODUKSI TANAMAN PANGAN INDONESIA
}

\author{
(The Roles of Fertilizer Application on Production Performance of Indonesian Food Crops)
}

\author{
Ririn Pamuncak, Bustanul Arifin, Eka Kasymir
}

Jurusan Agribisnis, Fakultas Pertanian, Universitas Lampung, Jl. Prof. Dr. Soemantri Brojonegoro No. 1 Bandar Lampung, 35155, Telp.089677000725, e-mail : ririnpamuncak17@ gmail.com

\begin{abstract}
This study aims to analyze the share of fertilizer costs on the total cost of crop and the effect of fertilizer application on the performance of crop production in Indonesia. The data used in the study was time series data, it was collected from FAOSTAT published Food and Agriculture Organization (FAO) and Statistics Center Bureou (BPS). The first objective was analyzed by descriptive statistics, whereras the second objective was analyzed by econometrics techniques, namely, linear production function, logarithmic function and quadratic function. The results showed that the percentage fertilizer cost on the total cost of crop production were quite small compared to the cost of labor and land rental, which were 10.40 percent for wetland paddy, 7.80 percent for upland paddy, 12.00 percent for maize, and 4.80 percent for soybean. The applications of fertilizer played important roles in production performance of paddy, maize, and soybean. The magnitude and significant level of each fertilizer differ by crop production. The study gives better policies to secure the availability of fertilizer to improve the performance of Indonesian crop production.
\end{abstract}

Key words: cost, fertilizer, production function

\section{PENDAHULUAN}

Negara Indonesia terkenal dengan sebutan negara agraris, hal ini dapat ditunjukkan dengan besarnya luas lahan yang digunakan untuk pertanian. Menurut data Badan Pusat Statistik (BPS) tahun 2014, sebagian luas lahan yang ada di Indonesia yaitu 71,33 persen digunakan untuk usaha pertanian. Pada tahun 2014 luas lahan yang digunakan untuk usaha pertanian mencapai 44,95 juta hektar.

Pertanian merupakan sektor yang mempunyai peranan strategis dalam perekonomian Indonesia. Berkaitan dengan fungsinya sebagai penyedia bahan pangan, penyedia lapangan pekerjaan, penyedia bahan baku industri dan sumber devisa bagi negara, maka perlu upaya untuk menjaga dan meningkatkan produktivitas dari pertanian dengan ketersediaan input yang mudah untuk diperoleh. Salah satu input yang memegang peranan penting dalam meningkatkan produksi adalah pupuk.

Mengingat peranan pupuk yang sangat strategis, maka penyediaan pupuk dengan harga yang terjangkau oleh petani merupakan masalah yang krusial. Berdasarkan regulasi saat ini, pengadaan dan penyaluran pupuk bersubsidi telah ditetapkan dan ditataniagakan dengan HET melalui penyaluran resmi. Kegiatan usahatani tanaman pangan khususnya padi, jagung, dan kedelai memerlukan input produksi seperti benih, pupuk, pestisida, biaya tenaga kerja, sewa lahan, pajak dan lain sebagainya. Perkembangan subsektor pertanian berbanding lurus dengan mahalnya biaya input produksi usahatani (Kariyasa 2004).

Kebijakan pemerintah yang berhubungan dengan investasi sektor pertanian yaitu subsidi yang diberikan pada sarana produksi pertanian, terutama pupuk melalui program subsidi harga pupuk. Subsidi harga pupuk bertujuan untuk membantu petani dalam penyediaan dan penggunaan pupuk sesuai kriteria. Pupuk bersubsidi merupakan pupuk yang pengadaan dan penyalurannya mendapat subsidi dari pemerintah untuk kebutuhan petani yang dilaksanakan atas dasar program pemerintah (SK Menteri Perindustrian dan Perdagangan No. 15/MDag/PER/4/2013).

Pupuk yang mendapat subsidi dari pemerintah tidak diberikan secara gratis tapi dapat dibeli dengan harga yang terjangkau. Pupuk yang disubsidikan oleh pemerintah adalah jenis pupuk Urea, SP-36, ZA, NPK dan pupuk organik. Jika dilihat selisih antara kebutuhan dan alokasi subsidi pupuk oleh pemerintah beberapa ibukota provinsi di Indonesia., maka kebutuhan pupuk yang lebih besar dari alokasi pupuk besubsidi 
menjadi salah satu faktor yang mempengaruhi kelangkan pupuk di Indonesia. Ketersediaan pupuk di lapangan sangat membantu petani untuk menjalankan usahataninya,namun banyak hal yang memepengaruhi kelangkaan pupuk dilapangan, seperti bahan baku pupuk yaitu kontibusi pasokan gas, realisasi permintaan pupuk, kontribusi APBN terhadap subsidi pupuk, dan nilai kurs.

Menurut BPS dan Permentan tahun 2015, bahwa biaya total produksi tanaman pangan padi, jagung dan kedelai selalu fluktuatif, dan cenderung meningkat pada tahun 2014 sebesar tiga persen untuk tanaman padi, tahun 2015 sebesar empat persen untuk tanaman jagung. Jika dilihat dari masing-masing input maka tiga urutan terbesar biaya input yaitu biaya tenaga kerja, biaya sewa lahan, dan biaya pupuk.

Kebutuhan pangan nasional setiap tahun selalu meningkat seiring dengan perkembangan jumlah penduduk. Produksi tanaman pangan khususnya padi, jagung, dan kedelai setiap tahun bisa dikatan stabil. Produksi padi dan kedelai yang tidak meningkat signifikan mengharuskan Indonesia untuk tetap impor untuk memenuhi kebutuhan pangan nasional.

Hipotesis awal permasalahan kelangkaan pupuk dari kebijakan subsidi pupuk oleh pemerintah diduga tidak terlalu berpengaruh secara signifikan terhadap kegiatan produksi usahatani tanaman pangan. Biaya input produksi tanaman pangan khususnya padi, jagung, dan kedelai juga meningkat setiap tahun. Ketidakseimbangan antara biaya dan produksi ini merupakan salah satu masalah yang di hadapi indonesia dibidang pertanian.

Masalah input yang timbul juga mendukung masalah produksi dalam negeri. Input pupuk yang dianggap cukup penting untuk meningkatkan produksi juga saat ini mengalami kelangkaan diseluruh wilayah di Indoneia. Perlu analisis lebih lanjut bagaimana input input yang dianggap akan mempengaruhi produksi.

Berdasarkan uraian permasalahan di atas, maka tujuan penelitian ini yaitu kebijakan subsidi pupuk dengan menganalisis berapa besar porsi biaya pupuk terhadap total biaya produksi tanaman pangan nasional dan menganalisis pengaruh penggunaan pupuk terhadap hasil produksi tanaman pangan nasional.

\section{METODE PENELITIAN}

Data yang digunakan dalam penelitian ini adalah data struktur biaya produksi usahatani padi, jagung, kedelai tahun 2014 yang bersumber dari Badan Pusat Satistik publikasi bulan September 2015 untuk tujuan pertama dengan menganalisis berapa besar porsi biaya pupuk terhadap total biaya produksi tanaman pangan, dan data runtun waktu (time series) dari FAO dengan kurun waktu 55 tahun untuk tujuan kedua dengan menganalisis bagaimana benih, luas lahan panen, pupuk Urea, pupuk ZA, pupuk NPK, dan pupuk SP36 mempengaruhi produksi tanaman pangan seperti padi, jagung, dan kedelai.

Metode yang digunakan untuk tujuan pertama dan kedua yaitu analisis deskriptif kuantitatif. Tujuan pertama yaitu analisis biaya produksi melalui pendekatan struktur biaya tanaman pangan pada BPS tahun 2014 dengan menganalisis bagaimana pengaruh biaya pupuk terhadap total biaya produksi tanaman pangan nasional khususnya padi sawah, padi ladang, jagung dan kedelai.

Pada tujuan kedua digunakan alat analisis regresi berganda dengan menggunakan Uji Kointegrasi Engle-Granger, dan Error Correction Model (ECM) untuk uji stasioneritas, uji heteroskedastisitas, uji autokorelasi dan uji statistik. Analisis uji statistik ini akan menggunakan tiga fungsi yaitu fungsi linier, fungsi logaritma, dan fungsi kuadrat dengan mendeskripsikan hasil ouptut. Pengujianpengujian ini dilakukan agar mendapat hasil yang baik (Gujarati 1998) seperti berikut :

Uji F digunakan untuk mengetahui apakah model penduga yang diajukan sudah layak untuk menduga parameter yang ada dalam fungsi serta mengatahui pengaruh bagaimana pengaruh peubah bebas terhadap peubah tidak bebas secara keseluruhan.

Hipotesis :

1. $\mathrm{H}_{0}: \mathrm{b} 1=\mathrm{b} 2 \ldots . .=\mathrm{bi}=0$

2. $\mathrm{H}_{1}$ : minimal ada salah satu $\mathrm{bi} \neq 0$

Kriteria uji :

1. Probability $F$-statistic $<$ taraf nyata $(\alpha)$, maka tolak $\mathrm{H}_{0}$ dan terima $\mathrm{H}_{1}$

2. Probability $F$-statistic $>$ taraf nyata $(\alpha)$, maka terima $\mathrm{H}_{0}$ dan tolak $\mathrm{H}_{1}$

Jika $\mathrm{H}_{0}$ ditolak berarti minimal ada satu variabel bebas yang berpengaruh nyata terhadap variabel terikat dan model layak digunakan, sebaliknya 
jika H0 diterima maka tidak ada satu variabel bebas yang berpengaruh nyata.

Uji t digunakan untuk mengetahui bagaimana pengaruh dari suatu model variabel bebas berpengaruh nyata atau tidak terhadap variabel tidak bebas.

Uji satu arah :

1. $\mathrm{H}_{0}: \mathrm{b} 1=\mathrm{b} 2=\ldots \ldots .=\mathrm{bi}=0$

2. $\mathrm{H}_{1}$ : bi $>0$ atau bi $<0$

Uji dua arah :

1. $\mathrm{H}_{0}: \mathrm{b} 1=\mathrm{b} 2=\ldots \ldots=\mathrm{bi}=0$

2. $\mathrm{H}_{1}: \mathrm{bi} \neq 0$

Kriteria uji :

1. Probability $t$-statistic $<$ taraf nyata $(\alpha)$, maka tolak $\mathrm{H}_{0}$ dan terima $\mathrm{H}_{1}$

2. Probability t-statistic $>$ taraf nyata $(\alpha)$, maka terima $\mathrm{H}_{0}$ dan tolak $\mathrm{H}_{1}$

Jika $\mathrm{H}_{0}$ ditolak berarti ada variabel bebas yang berpengaruh nyata terhadap variabel terikat dan model layak digunakan, sebaliknya jika $\mathrm{H}_{0}$ diterima maka tidak ada variabel bebas yang berpengaruh nyata terhadap variabel tidak bebas.

Koefisien determinasi digunakan untuk melihat seberapa besar keragaman yang dapat diterangkan oleh variabel bebas terhadap variabel tidak bebas. Kofisien determinasi memiliki dua sifat yaitu $\mathrm{R}^{2}$ merupakan besaran non negative dan nilainya $\mathrm{R}^{2}$ adalah $0 \leq \mathrm{R}^{2} \leq 1$, dimana bila $\mathrm{R}^{2}$ mendekati 1 berarti model tersebut dapat dikatakan semakin baik karena semakin dekat hubungan antar variabel bebas terhadap variabel tidak bebas, demikian pula sebaliknya.

Suatu model dikatakan baik apabila telah memenuhi asumsi tidak terdapat gejala autokorelasi. Uji autokorelasi bertujuan untuk menguji apakah hasil estimasi model tidak mengandung korelasi serial diantara disturbance term.

Pada program Eviews 9.1, uji autokorelasi dilakukan dengan melihat Probability Obs*Rsquare pada uji Breunch And Godfrey Serial Correlation LM-Test. Jika nilai probabilitas $O b s^{*} R$-Square lebih besar dari taraf nyata maka tidak mengalami autokorelasi, sebaliknya bila nilai probabilitas $O b s * R$-Square lebih kecil dari taraf nyata maka mengandung autokorelasi.
Heteroskedastisitasitas terjadi jika ragam tidak konstan. Akibat dari heteroskedastisitasitas ini menyebabkan sifat BLUE (Best Linier Unbiased Estimate) tidak tercapai atau pengujiannya tidak valid. Gejala adanya heteroskedastisitasitas ditunjukan oleh Probability $O b s^{*}$-Square pada uji White Heteroskedasticity. Jika nilai probabilitas $O b s^{*} R$-Square lebih besar dari taraf nyata maka tidak mengalami heteroskedastisitasitas, sebaliknya bila nilai probabilitas $O b s^{*}$ Rsquare lebih kecil dari taraf nyata maka mengandung heteroskedastisitasitas.

Data yang stasioner adalah data yang nilai ratarata dan variannya tidak mengalami perubahan secara sistematik sepanjang waktu, atau rata-rata dan variannya konstan. Untuk menguji apakah data bersifat stasioner atau tidak, terdapat banyak uji akar unit, tetapi yang umum dan banyak dipakai adalah Augmented Dickey Fuller Test (ADF). Konsep pengujian Augmented Dickey Fuller Test adalah jika suatu data time series tidak stasioner pada orde nol, I(0), maka ditingkatkan stasioneritas pada ordo ke-n (first difference) atau second difference atau $\mathrm{I}(2)$ (Purnomo 2010).

\section{HASIL DAN PEMBAHASAN}

\section{Analisis Biaya Pupuk Terhadap Total Biaya Produksi Tanaman Pangan}

Pada analisis ini dapat dilihat bagaimana pengaruh biaya pupuk yang dipakai dalam kegiatan usahatani terhadap total biaya produksi. Pada Tabel 1 dapat dijelaskan perbandingan biaya pupuk terhadap total biaya produksi untuk tanaman padi sawah, padi ladang, jagung dan kedelai.

Tabel 1. Analisis biaya pupuk terhadap total biaya produksi pada sawah, padi ladang, jagung, dan kedelai tahun 2014

\begin{tabular}{lccc}
\hline $\begin{array}{c}\text { Tanaman } \\
\text { Pangan }\end{array}$ & $\begin{array}{c}\text { Total Biaya } \\
\text { Pupuk } \\
\text { (juta/ha) }\end{array}$ & $\begin{array}{c}\text { Total Biaya } \\
\text { Produksi } \\
\text { (juta /ha) }\end{array}$ & $\begin{array}{c}\% \text { Biaya } \\
\text { Pupuk/ } \\
\text { Biaya } \\
\text { Produksi }\end{array}$ \\
\hline Padi Sawah & 1,30 & 12,70 & 10,40 \\
Padi Ladang & 0,60 & 7,80 & 7,80 \\
Jagung & 1,10 & 9,10 & 12,00 \\
Kedelai & 0,40 & 9,10 & 4,80 \\
\hline Sumber : Data diolah 2016 & &
\end{tabular}

Sumber : Data diolah 2016 
Pada tahun 2014 untuk padi sawah 10,4 persen biaya pupuk bersubsidi ikut andil dalam total biaya produksi yaitu Rp1.300.000 per musim tanam per ha dari total biaya produksi sebesar Rp12.700.000. Secara keseluruhan biaya yang lebih besar dan perlu diperhatikan oleh pemerintah selain biaya pupuk yang hanya 10,4 persen yaitu biaya sewa lahan dan upah pekerja dalam kegiatan usahatani padi sawah. Biaya upah pekerja sebesar 35,90 persen atau sekitar Rp4.500.000. Biaya sewa lahan sebesar Rp3.800.000 atau sekitar 29,90 persen dari total biaya produksi sebesar sebesar Rp12.700.000 dengan total produksi jika dalam Rupiah yaitu Rp17.200.000.

Pada Tabel 1 tahun 2014 untuk padi ladang 7,8 persen biaya pupuk ikut andil dalam total biaya produksi yaitu Rp600.000 per musim tanam per ha dari total biaya produksi sebesar Rp7.800.000. Secara keseluruhan terdapat biaya yang lebih besar dan perlu diperhatikan oleh pemerintah selain biaya pupuk yang 7,8 persen yaitu biaya sewa lahan dan upah pekerja. Biaya upah pekerja sebesar 58,80 persen atau sekitar Rp4.600.000. Biaya sewa lahan sebesar Rp1.400.000 atau sekitar 17,70 persen dari total biaya produksi sebesar sebesar Rp7.800.000 dengan total produksi jika dalam Rupiah yaitu Rp10.300.000. Pada Tabel 1 tahun 2014 hanya 12 persen biaya pupuk ikut andil dalam total biaya produksi yaitu Rp1.100.000 per musim tanam per ha dari total biaya produksi sebesar Rp9.100.000. Secara keseluruhan ada biaya yang lebih besar dan perlu diperhatikan oleh pemerintah dari sekedar biaya pupuk yang hanya 12 persen yaitu biaya upah pekerja dan sewa. Biaya sewa lahan sebesar Rp2.500.000 atau sekitar 27,70 persen dari total biaya produksi dan untuk upah pekerja sebesar Rp3.700.000 atau sekitar 40,90 persen dari total biaya produksi dengan total produksi jika dalam Rupiah yaitu Rp12.000.000.

Pada Tabel 1 tahun 2014 hanya 4,8 persen untuk biaya pupuk ikut andil dalam total biaya produksi yaitu Rp400.000 per musim tanam per ha dari total biaya produksi sebesar Rp9.100.000, biaya yang lebih besar dan perlu diperhatikan oleh pemerintah dari sekedar biaya pupuk yang hanya 4,8 persen yaitu biaya upah pekerja dan sewa lahan. Biaya sewa lahan sebesar Rp.3.300.000 atau sekitar 35,60 persen dan untuk upah pekerja sebesar Rp3.600.000 atau sekitar 39,90 persen dari total biaya produksi dengan total produksi jika dalam Rupiah yaitu Rp9.000.000,00.

\section{Hasil Analisis Uji Ekonometrika}

Pengujian dilakukan dengan Eviews 9 untuk pengujian data time series yaitu uji stasioner dengan uji root test. Pada lampiran 2, 3 dan 4 uji stasioner pada ordo first difference dan second difference. Setelah pengujian data time series dilakukan analisis error correction model (ECM). Hasil output untuk analisis tujuan ketiga dan pengujian selanjutnya yaitu uji heteroskedastisitas dengan uji white menggunakan Eviews 9, jika hasil analisis regresi berganda dengan fungsi linier, logaritma, dan kuadrat untuk tanaman padi memiliki masalah heteroskedastisitas karena chisquare <0,05, namun jika chi-square >0,05 maka dapat dijelaskan bahwa fungsi ini bebas masalah heteroskedastisitas dan dapat meneruskan pada pengujian selanjutnya yaitu uji autokorelasi.

Pengujian selanjutnya yaitu uji autokoreasi dengan melihat nilai Durbin Watson (DW) pada uji Breusch-Godfrey Serial Correlation LM dengan Eviews 9. Nilai DW dibandingkan dengan tabel DW pada taraf kepercayaan 5\%.

\section{Hasil Analisis Uji Statistik}

Dari ketiga Tabel 2, 3, dan 4 maka dapat disimpulkan bahwa rata-rata R-square dan Adj RSquare untuk padi, jagung, dan kedelai pada tiga fungsi yaitu linier, logaritma, dan kuadrat 90 persen. Uji F statistik semua F-hitung lebih besar dari F-tabel sehingga dapat dikatakan bahwa secara bersama-sama pengggunaan pupuk berpengaruh nyata terhadap produksi tanaman pangan nasional. Dari sisi lain jika dikaitkan dengan solusi ketimpangan maka kebijakan pemerintah yang tidak efektif misalanya subsidi pangan, subsidi pendidikan, subsidi pupuk dan lin-lain, sekitar 65 persen petani termiskin menerima 3 persen subsidi pupuk, tapi 1 persen petani terkaya telah menikmati 70 persen subsidi pupuk, dan 5 persen petani terkaya menikmati 90 persen subsidi. Oleh karena itu kebijakan distribusi yang tidak tepat sasaran ikut berkontribusi pada peningkatan ketimpangan pendapatan, begitu sebaliknya secara positif kebijakan subsidi pupuk dan distribusi pupuk yang tepat sasaran mampu berkontribusi pada penurunan ketimpangan pendapatan.

Jika dikaitkan dengan kenyataan yang ada biaya sewa lahan dan tenaga kerja memang lebih dominar dari total biaya jika dibandingan dengan total biaya pupuk., sehingga dapat dikatakan subsisdi pupuk perlu dikaji kembali dalam penerapannya. Biaya produksi padi di Indonesia 
JIIA, VOLUME 6 No. 3, AGUSTUS 2018

2,5 kali dari biaya produksi padi di Vietnam pada tahun 2017.

Namun ada masalah lain selain itu, biaya perawatan tanaman dan panen di Indonesia lebih mahal, tetapi upah pekerja di Indonesia paling rendah jika dibandingkan beberapa negara di AsiaTenggara, karena semakin luas lahan yang digunakan petani dalam usahatani tanaman pangan khususnya padi, jagung atau kedelai maka akan banyak pula pupuk yang akan digunakan, begitu sebaliknya. Penelitian ini memberikan saran bahwa perlu kebijakan yang lebih baik untuk menjamin ketersediaan pupuk guna meningkatkan kinerja produksi tanaman pangan yang stategis.

Tabel 2. Perbandingan fungsi produksi padi total periode 1961-2015 menggunakan fungsi linier, logaritma, dan kuadrat

\begin{tabular}{|c|c|c|c|}
\hline & Linier & Logaritma & Kuadrat \\
\hline \multicolumn{4}{|l|}{ Variabel Bebas } \\
\hline \multirow{2}{*}{ Konstanta } & $(-43494442)^{*}$ & $(-1804.248)^{*}$ & $(1.38 \mathrm{E}+15)^{*}$ \\
\hline & -14.6729 & -8.9570 & -14.7598 \\
\hline \multirow{2}{*}{ Benih } & $(25.6973)^{*}$ & $(0.3315)^{*}$ & $(1908.925)^{*}$ \\
\hline & 3.1074 & 2.5668 & 2.1853 \\
\hline \multirow{2}{*}{ Luas Panen } & $(7.0791)^{*}$ & $(1.9230)^{*}$ & $(26.3355)^{*}$ \\
\hline & 12.8731 & 9.7766 & 13.3443 \\
\hline \multirow{2}{*}{ Pupuk Urea } & $(-0.2006)^{*}$ & $(-0.0745)^{*}$ & $(18.5764)^{*}$ \\
\hline & -0.2342 & -0.2141 & 1.3411 \\
\hline \multirow{2}{*}{ Pupuk ZA } & $(0.6288)^{*}$ & $(1.5078)^{*}$ & $(-99.9560)^{*}$ \\
\hline & 0.0947 & 2.3787 & -0.1609 \\
\hline \multirow{2}{*}{ Pupuk NPK } & $(-0.1242)^{*}$ & $(-0.8371)^{*}$ & $(151.1080)^{*}$ \\
\hline & -0.0847 & -3.0731 & 2.3968 \\
\hline \multirow[t]{2}{*}{ Pupuk SP36 } & $(5.0743)^{*}$ & $(0,7843)^{*}$ & $(110.1329)^{*}$ \\
\hline & 2.4640 & 1.3763 & 0.7769 \\
\hline \multicolumn{4}{|l|}{ Uji Statistik } \\
\hline R-Square & $0.9908 * *$ & $0.9832 * *$ & $0.9923 * *$ \\
\hline Adj R-Square & $0.9887 * *$ & $0.9811 * *$ & $0.9913 * *$ \\
\hline F-Statistik & 865.8612 & 469.0719 & 1036.008 \\
\hline Prob. F-Statistik & 0.0000 & 0.0000 & 0.0000 \\
\hline F- Hitung & 2.4000 & 2.4000 & 2.4000 \\
\hline
\end{tabular}

* nyata pada taraf 80 persen, **nyata pada taraf 95 persen, () adalah t statistik

Tabel 3. Perbandingan fungsi produksi jagung periode 1961-2015 menggunakan fungsi linier, logaritma dan kuadrat

\begin{tabular}{|c|c|c|c|}
\hline & Linier & Logaritma & Kuadrat \\
\hline \multicolumn{4}{|l|}{ Variabel Bebas } \\
\hline \multirow{2}{*}{ Konstanta } & $(-4760072)^{*}$ & $(-1284.103) *$ & $(-3.53 \mathrm{E}+13)^{*}$ \\
\hline & -5.1665 & -5.6785 & -4.8512 \\
\hline \multirow{2}{*}{ Benih } & $(37.4581)^{*}$ & $(0.6188)^{*}$ & $(3658.916)^{*}$ \\
\hline & 4.2185 & 5.4063 & 5.0431 \\
\hline \multirow{2}{*}{ Luas Panen } & $(1.9131)^{*}$ & $(1.3845)^{*}$ & $(4.3669) *$ \\
\hline & 6.0823 & 8.0546 & 5.3621 \\
\hline \multirow{2}{*}{ Pupuk Urea } & $(5.9944)^{*}$ & $(0.0344)^{*}$ & $(94.3519)^{*}$ \\
\hline & 5.2417 & 0.0416 & 6.2079 \\
\hline \multirow{2}{*}{ Pupuk ZA } & $(-16.8116)^{*}$ & $(4.5048)^{*}$ & $(-1204.726)^{*}$ \\
\hline & -1.7753 & 4.0581 & -1.7579 \\
\hline \multirow{2}{*}{ Pupuk NPK } & $(9.3955)^{*}$ & $(1.5705)^{*}$ & $(532.2761)^{*}$ \\
\hline & 3.9510 & 2.1631 & 6.7092 \\
\hline \multirow[t]{2}{*}{ Pupuk SP36 } & $(8.8294) *$ & $(2.7260)^{*}$ & $(34.7861)^{*}$ \\
\hline & 3.2781 & 2.1160 & 0.2280 \\
\hline \multicolumn{4}{|l|}{ Uji Statistik } \\
\hline R-Square & $0.9778 * *$ & $0.9551 * *$ & $0.9872 * *$ \\
\hline Adj R-Square & $0.9751 * *$ & $0.9453 * *$ & $0.9856^{* *}$ \\
\hline F-Statistik & 353.8880 & 156.5983 & 618.0893 \\
\hline Prob. F-Statistik & 0.0000 & 0.0000 & 0.0000 \\
\hline F- Hitung & 2.4000 & 2.4000 & 2.4000 \\
\hline
\end{tabular}


Tabel 4. Perbandingan fungsi produksi kedelai periode 1961-2015 menggunakan fungsi linier, logaritma, dan kuadrat

\begin{tabular}{|c|c|c|c|}
\hline & Linier & Logaritma & Kuadrat \\
\hline \multicolumn{4}{|l|}{ Variabel Bebas } \\
\hline \multirow{2}{*}{ Konstanta } & $(-393581.1)^{*}$ & $(-534.3116)^{*}$ & $(3.61 \mathrm{E}+11)^{*}$ \\
\hline & -8.0634 & -8.0483 & -8.6037 \\
\hline \multirow{2}{*}{ Benih } & $(6.8694)^{*}$ & $(0.5263)^{*}$ & $(147.8183)^{*}$ \\
\hline & 2.9989 & 7.4144 & 3.3580 \\
\hline \multirow{2}{*}{ Luas Panen } & $(1.0780)^{*}$ & $(0.9710)^{*}$ & $(1.2121)^{*}$ \\
\hline & 15.5606 & 16.2048 & 17.6349 \\
\hline \multirow{2}{*}{ Pupuk Urea } & $(0.6874)^{*}$ & $(-0.4239)^{*}$ & $(10.4625)^{*}$ \\
\hline & 2.2287 & -1.1290 & 2.7875 \\
\hline \multirow{2}{*}{ Pupuk ZA } & $(4.9076)^{*}$ & $(1.0866)^{*}$ & $(-143.5437)^{*}$ \\
\hline & 1.3348 & 1.6583 & -0.6875 \\
\hline \multirow{2}{*}{ Pupuk NPK } & $(0.3065)^{*}$ & $(2.5482)^{*}$ & $(35.1568)^{*}$ \\
\hline & 0.3337 & 5.7665 & 1.5203 \\
\hline \multirow{2}{*}{ Pupuk SP36 } & $(-1.2160)^{*}$ & $(0.3086)^{*}$ & $(-74.3406)^{*}$ \\
\hline & -0.9805 & 0.4654 & -1.9369 \\
\hline \multicolumn{4}{|l|}{ Uji Statistik } \\
\hline R-Square & $0.9759 * *$ & $0.9796 * *$ & $0.9791 * *$ \\
\hline Adj R-Square & $0.9729 * *$ & $0.9771 * *$ & $0.9765^{* *}$ \\
\hline F-Statistik & 324.9967 & 285.1919 & 375.7240 \\
\hline Prob. F-Statistik & 0.0000 & 0.0000 & 0.0000 \\
\hline F- Hitung & 2.4000 & 2.4000 & 2.4000 \\
\hline
\end{tabular}

\section{KESIMPULAN}

Hasil analisis melalui pendekatan biaya produksi tahun 2014 menunjukkan bahwa persentase biaya pupuk terhadap total biaya produksi tanaman padi sawah hanya 10,40 persen dari total biaya produksi, padi ladang hanya 7,80 persen dari total biaya produksi, jagung hanya 12,00 persen dari total biaya produksi, dan kedelai hanya 4,80 persen dari total biaya produksi. Biaya pupuk hanya berada pada urutan ketiga setelah biaya upah tenaga kerja dan biaya sewa lahan.

Rata-rata R-square dan Adj R-Square variabel bebas terhadap variabel terikat yaitu produksi untuk padi, jagung, dan kedelai pada tiga fungsi yaitu linier, logaritma, dan kuadrat 90 persen. Variabel pupuk yang tidak berpengaruh terhadap produksi tanaman pangan untuk padi yaitu pupuk ZA dan NPK, untuk jagung yaitu pupuk urea, dan untuk kedelai yaitu pupuk ZA dan SP-36.

\section{DAFTAR PUSTAKA}

Badan Pusat Statistik. Lahan Pertanian di Indonesia, Tahun 2010-2014. Diakses pada tanggal 4 April 2016. http://www.bps.go.id.
2016. Nilai Produksi dan Biaya Produksi per Musim Tanam per Hektar Budidaya Padi sawah, Padi Ladang, Jagung, dan Kedelai, 2014. http://www.bps.go.id. [2 Maret 2017].

Gujarati D. 1998. Ekonometrika Dasar. Jakarta: Erlangga.

Kariyasa K. 2004. Usulan tingkat subsidi dan harga eceran tertinggi (HET) yang relevan serta perbaikan pola pendistribusian pupuk di Indonesia. Analisis Kebijakan Pertanian, 2 (3): 277-287.

Kementerian Keuangan 2009. Nota Keuangan dan RAPBN (2009). http://www.anggaran.dep keu.go.id. [25 Desember 2015].

Kementerian Perdagangan. 2013. Surat Keputusan Menteri Perdagangan No. 03/MDAG/PER/2/2013 Tentang Pengawasan Distribusi Pupuk Bersubsidi.

Kementerian Pertanian. 2015. Surat Keputusan Menteri Pertanian pasal 12 ayat 1 Tentang Alokasi dan Kebutuhan serta Harga Eceran Tertinggi (HET) Pupuk Bersubsidi Untuk Sektor Pertanian Tahun Anggaran 2015. 